\title{
PENINGKATAN KEMAMPUAN KOMUNIKASI MELALUI PERMAINAN MEMASANGKAN GAMBAR DENGAN KATA DI TAMAN KANAK-KANAK CIREBON
}

\author{
Maulidya Ulfah \\ IAIN Syekh Nurjati Cirebon \\ E-mail: ulfah.003@gmail.com \\ Evana \\ Guru TK Nurul Wathoni \\ E-mail: evanaeva42@ gmail.com
}

Article received: 12 Maret 2018 Review process: 15 Maret 2018

Article published: 30 Maret 2018

\begin{abstract}
Communication can be seen as the process of publicizing information to others who will convey a message message from a child, the day off. Then the 5-6 year old child was able to convey information to the parents what information obtained from the teacher class. When children communicate with peers, both seen from the child playing and talking about his favorite object accidentally the child can communicate well. Problems found in the school children have not been able to mention letters, because of these factors children do not have a lot of vocabulary, so that in communicating the child is difficult in communication with his friends and teachers, and parents. This study aims to: 1) Know the ability of communicating children in groups in kindergarten Nurul Wathoni Cirebon, 2) Knowing Improved communication skills in group B in kindergarten Nurul Wathoni Cirebon, 3) Knowing the game Pair image with keywords in group B in kindergarten Nurul Wathoni Cirebon. This research method uses Class / PTK action research. Subjects of B-class students TK Nurul Wathoni Cirebon, which consists of 21 children, in Kedawung District Cirebon District. Data analysis techniques that researchers use are interviews, observation, and documentation. The results of this study indicate that there is an increase in communication skills of children on the game pair with the word in group B in TK Nurul Wathoni Cirebon before given the action or percentage of Pre Cycle 19.04\%, the cycle I of the presentation is $47.61 \%$, while in cycle II $85.71 \%$, it can be concluded its existence between Cycle I Cycle I of $28.57 \%$, so the difference between the percentage of Cycle I to Cycle II is $38.1 \%$.
\end{abstract}

Keywords: Communication, Pairing Image With Words, Early Childhood

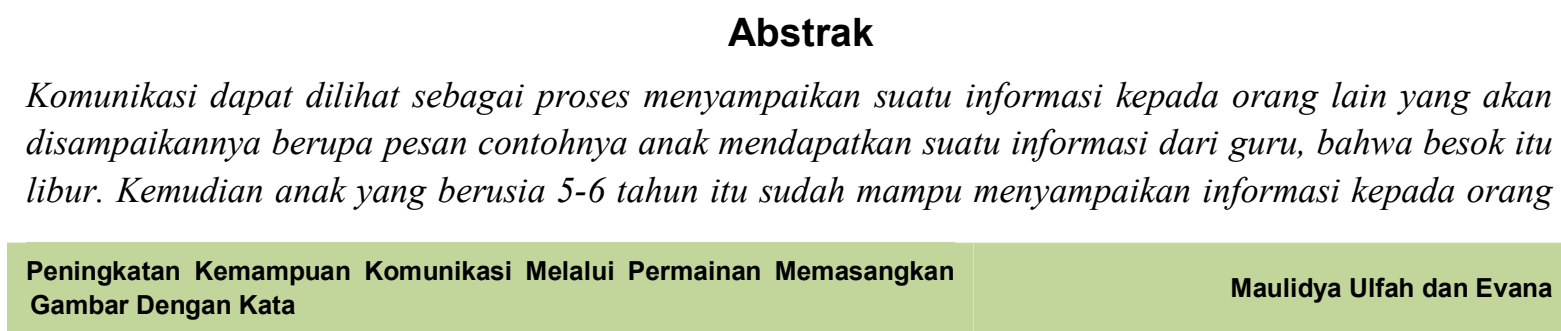


tua apa yang didapat suatu informasi tersebut, dari guru kelasnya. Ketika anak berkomunikasi dengan teman sebayanya, baik dilihat dari anak itu bermain maupun berbicara mengenai benda kesukaannya dengan tidak tidak sengaja anak dapat berkomunikasi dengan baik. Masalah yang ditemukan disekolah itu anak belum mampu menyebutkan huruf, karena dari faktor tersebut anak belum mempunyai kosa kata yang banyak, sehingga dalam berkomunikasi anak sulit dalam komunikasi dengan temannya maupun guru, dan orang tua. Penelitian ini bertujuan untuk: 1) Mengetahui Kemampuan komunikasi anak pada kelompok di TK Nurul Wathoni Cirebon, 2) Mengetahui Peningkatan Kemampuan komunikasi pada kelompok B di TK Nurul Wathoni Cirebon, 3) Mengetahui Permainan Memasangkan gambar dengan kata diterapkan pada kelompok B di TK Nurul Wathoni Cirebon. Metode penelitian ini menggunakan Penelitian Tindakan Kelas/PTK. Subjek penelitian anak didik Kelompok B TK Nurul Wathoni Cirebon, yang terdiri dari 21 anak, di Kecematan Kedawung Kabupaten Cirebon. Teknik analisis data yang peneliti gunakan adalah wawancara, observasi, dan dokumentasi. Hasil penelitian ini menunjukkan bahwa peningkatan kemampuan komunikasi anak melalui permainan memasangkan gambar dengan kata pada kelompok B di TK Nurul Wathoni Cirebon pada sebelum diberi tindakan atau Pra Siklus presentasenya adalah 19,04\%, pada Siklus I presentasenya adalah 47,61\%, sedangkan pada siklus II presentasenya adalah 85,71\%, Jadi dapat disimpulkan bahwa presentase antara Pra Siklus ke Siklus I yaitu 28,57 \%, sehingga selisih antara presentase Siklus I ke Siklus II yaitu 38,1 \%.

Kata Kunci: Komunikasi, Permainan Memasangkan Gambar Dengan Kata, Anak UsiaDini

\section{PENDAHULUAN}

Menurut Mulyana dalam komunikasi seseorang yang akan melakukan suatu hal yang akan dilakukannya baik itu makan, minum, berbicara pasti adanya komunikasi dengan orang lain. Karena komunikasi itu cara-cara berperilaku yang harus dipelajari lewat pengasuhan keluarga dan pergaulan dengan orang lain maka menggunakan dengan komunikasi. Orang tidak pernah berkomunikasi dengan manusia, bisa dipastikan akan diam dan bila berkomunikasi dengan orang lain. Maka orang tersebut akan sulit dalam komunikasi karena kurangnya kosa kata (Mulyana, 2005: 5).

Seorang anak mulai berkomunikasi dengan orang lain itu dimulai dengan orang yang paling dekat, salah satunya itu dari ibu, ayah, dan anggota keluarga lainnya yang memberikan sebuah ekspresikan melalui tangisan, senyum, atau gerak gerik ekspresi tersebut merupakan tanda bahwa ia membutuhkan sesuatu sesuai dengan keinginannya. Seorang yang paling peka memahami bahasa dalam komunikasi dalam kehidupan sehari-hari adalah ibu.Kepekaan ibu itu muncul pada saat ia menyusui atau menidurkan anaknya. Di saat inilah bunyi-bunyi bahasa dihasilkan dan diwujudkan dalam kalimat satu kata, dua kata, atau lebih dari tiga kata.Komunikasi yang dibangun oleh orang tua sangat mendukung dalam perkembangan pada 
kemampuan komunikasi berbicara anak.Factor yang mendukung anak untuk berkembang dalam berbicara yang salah satunya dengan menggunakan kalimat-kalimat sederhana dimulai dengan benda-benda yang ada di sekitar rumah terlebih dahulu. Salah satu faktor penting yang dapat dimanfaatkan orang tua untuk melatih anak berbicara yaitu dengan menggunakan cerita-cerita yang menarik dan diminati oleh anak.Orang tua harus menyediakan waktu untuk anak walaupun ada pekerjaan yang sangat sibuk maka harus adanya waktu kosong bersama anak untuk berkomunikasi dengan anaknya dengan melaui bercerita.

Komunikasi apa pun yang mau disampaikan oleh individu atau kelompok kepada orang lain adalah dengan maksud dan tujuan yang bermacam-macam. Karena dalam itu komunikasi yang dilakukan oleh individu atau kelompok itu tidak terlalu sama, tetapi dengan taraf kedalaman yang berbeda-beda. Taraf dalam komunikasi itu dapat di ukur dari apa dan siapa yang saling dibicarakan; pikiran atau perasaan, objek tertentu, orang lain, atau dirinya sendiri. Semakin orang mau saling membicarakan tentang perasaan yang ada dalam dirinya, objek tertentu atau orang lain, semakin dalam pula taraf komunikasi yang terjadi. Berdasarkan taraf komunikasi menurut John Powell bahwa membedakan komukasi itu ada dalam lima taraf, yaitu taraf basa-basi, membicarakan orang lain, orang yang menyatakan gagasan dan suatu pendapat kepada orang lain maka melalui dengan komunikasi, mengungkapkan isi hati atau perasaan(Djamarah, 2014: 10-11).

Adapun dalam firman Allah dalam surat al-alaq ayat 1 yang berbunyi sebagai berikut:

Bacalah dengan (menyebut nama tuhanmu yang menciptakan (Q.S Al-alaq : 1).

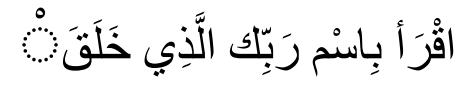

Jadi seseorang itu harus mengucapkan atau berkomunikasi dengan Allah yang telah menciptakan. Berkomunikasi dengan Allah itu dengan cara shalat, membaca alquran, dan berdzikir. Dalam hadits Tirmidzi (No 247) dari Abu Sa'id Al -Khudri, Nabi Shallahu ‘alaihi wa sallam bersabda:

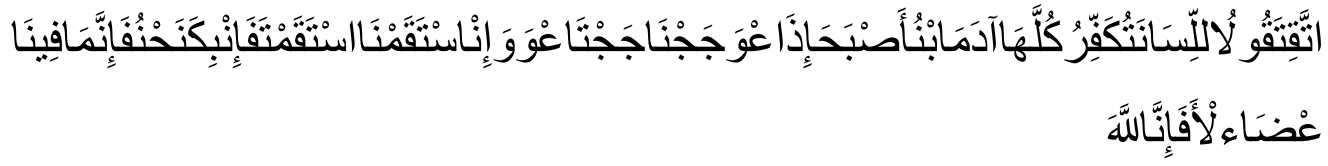

"Jika anak adam memasuki pagi hari, sesungguhnya semua anggota badannya berkata merendah kepada lisan. "tawakalah kepada Allah dalam menjaga hak-hak kami. Sesungguhnya kami ini tergantung kepadamu.Jika engkau istiqomah, maka kami juga istiqomah. Jika engkau menyimpang (dari jalan petunjuk), kami juga menyimpang". 
Jadi bahwa seorang anak itu harus menjaga lisannya ketika berbicara dengan orang lain harus sopan. Maka anak tersebut sama saja bertaqwa kepada allah karena menjaga perkataan yang baik. Jika anak beristiqomah dalam melakukan berbicara yang baik, sopan, maka anak sudah mampu beristiqomah kepada allahdengan dirinya sendiri.Kemudian berkaitan dengan permainannya yaitu anak dapat menyebutkan kata dengan baik, ketika memasangkan gambar dengan kata.

Berdasarkan penelitian awal tanggal 1 maret tahun 2017 bahwa perkembangan bahasa adalah salah satu dari berkomunikasi.Bahwa dalam berkomunikasi ini sering sekali dilakukan oleh setiap anak.Misalnya anak itu melakukan komunikasi dengan temannya. Akan tetapi, beberapa anak yang kurang berkomunikasi dengan temannya.Sehingga dalam berkomunikasi pun jarang dengan anak. Disekolah anak pun hanya terdiam, tidak ada berkomunikasi dengan temannya, saat ia bermain. Anak belum mampu menyebutkan huruf ketika melakukan pembelajaran di kelas kemudian peneliti memberikan permainan dalam memasangkan gambar dengan kata yang bertujuan untuk mengenalkan huruf pada anak.

Berdasarkanpengamatan di TK Nurul Wathoni Kota Cirebon, dan permasalahan dari pengalaman PPL,bahwa terkadang orang tua yang sibuk dalam pekerjaannya masing-masing. Bahkan anak jarang sekali berkomunikasi dengan orang tua, maka terjadilah disekolahnya pun anak kurang berkomunikasi sesama teman sebayanya, itulah yang terjadi pada anak. Anak itu memiliki yang kurangnya komunikasi dari orang tuanya, dan bahkan anak pun dipaksa untuk berinteraksi dengan lingkungan sekitar agar anak itu bisa berkmunikasi dengan melalui berinteraksi sosial dengan lingkungannya.

Peneliti mengambil sampel di kelompok B pada usia 5-6 tahun TK Nurul Wathoni Kota Cirebon terkadang susah untuk berkomunikasi dengan temannya. oleh karena itu peneliti memberikan permainan memasangkan gambar dengan kata dengan tujuan untuk melihat perkembangan bahasa anak dalam aspek perkembangan anak agar anak mampu komunikasi dengan temannya dari situlah adanya komunikasi dengan teman kelasnya.

Pada kesimpulannya bahwa komunikasi adalah inti dari semua hubungan dengan tingkat kedalam yang bervariasi. Perkembangan bahasa tersebut sangat penting dilakukan pada anak usia dini, karena dapat memberikan stimulus pada anak agar tidak terdapat hambatan dalam 
proses belajar. Ketika anak memiliki kemampuan komunikasi yang rendah dapat mengakibatkan berbagai hambatan dalam proses berbicara, seperti: anak sulit berkomunikasi dengan teman.

\section{KAJIAN TEORETIK}

Komunikasi menurut etimologi atau menurut asal katanya, istilah komunikasi berasal dari bahasa latin, yaitu communicatio, yang akar katanya adalah communis, tetapi bukan partai komunis dalam kegiatan politik. Arti communis disini adalah sama, dalam arti kata sama makna, yaitu sama makana mengenai suatu hal (Effendy, 2008: 3).

Jadi, komunikasi berlangsung bila orang-orang yang terlihat terdapat kesamaan mengenai suatu hal yang dikomunikasikan.Disini pengertian diperlukan agar komunikasi dapat berlangsung, sehingga hubungan mereka itu bersifat komunikatif.Sebaliknya jika tidak ada pengertian, komunikasi tidak berlangsung, hubungan antara orang-orang itu dikatakan tidak komunikatif (Djamarah, 2014: 13).

Komunikasidapat dilihat sebagai proses menyampaikan suatu informasi kepada orang lain yang akan disampaikannya berupa pesan contohnya anak mendapatkan suatu informasi dari guru, bahwa besok itu libur. Kemudian anak yang berusia 5-6 tahun itu sudah mampu menyampaikan informasi kepada orang tua apayang didapat suatu informasi tersebut, dari guru kelasnya. Ketika anak berkomunikasi dengan teman sebayanya, baik dilihat dari anak itu bermain maupun berbicara mengenai benda kesukaannya dengan tidak tidak sengaja anak dapat berkomunikasi dengan baik.Suatu dalam keberhasilan suatu komunikasi itu sangat penting dari penugasaan atau materi dan pengaturan dari cara-cara dalam penyampaiannya, sedangkan pengirim informasi dan penerima pesan bukan merupakan komponen yang menentukan dari situlah terjadi pada komunikasi.

Komunikasi diartikan sebagai proses penciptaan arti pada tahap gagasan atau ide yang akan disampaikannya dengan melaui pikiran seseorang dengan menggunakannya secara kreatif. Pengertian inidapat memberikan pesan yang seimbang antara pegirim dan penerima pesan yang merupakan tiga komponen utama dalam proses komunikasi. Pesan yang dapat disampaikan dengan berbagai melalui media namun pesan itu mepunyai arti jika pengirim dan penerima pesan berusaha menciptakan arti dari penyampaian pesan tersebut (Djamarah, 2014 : 13-14).

Teori komunikasi yang sangat sering diterapkan dan sederhana adalah teori komunikasi Berlo.Teori ini mengembangkan wawasan KBM pada kelas konvensional sebagai suatu komunikasi.Menurut teori Berlo ini dalam suatu KBM konvensional, maka pegajar adalah 
pengirim pesan yaitu materi ajar. Saluran yang digunakan untuk menyampaikan pesan tersebut bisa saja segala potensi pengajar yang akan dijadikan sebagai menyampaikan pesan, dalam media pembelajaran serta indra yang dimiliki oleh anak. Lalu anak sebagai penerima pesan atau topik yang disampaikan oleh pengajar untuk mencerna materi yang telah disampaikannya(prawiradilaga, 2007:23).

Permainan memasangkan gambar dengan kata komunikasi anak dapat dikembangakan dengan melalui perrmainan memasangkan gambar dengan kata.Bahwa anak itu membutuhkan pembelajaran yang menyenangkan yang salah satunya itu melalui permainan. Dengan melalui permainan anak dapat mengembangkan komunikasinya, yang salah satunya itu dengan cara permainan memasangkan gambar dengan kata agar anak itu tidak bosan dalam pembelajarannya yaitu yang salah satunya dengan cara sebagai berikut:

Tujuan dari Komunikasi dalam permainan memasangkan gambar dengan kata dengan tujuan untuk menstimulasi kecerdasan verbal linguistik pada anak (Madyawati, 2012: 21).Alat dan bahan berdasarkan permainan memasangkan gambar dengan kata yang berkaitan pada komunikasi anak. Permainan tersebut memiliki alat dan bahan yang harus diterpenuhi dalam permainan terhadap anak. Yaitu yang salah satunya pada gambar buah-buahan (nanas, rambutan, anggur, belimbing, dan lain-lainnya), tulisan nama buah-buahan (Madyawati, 2012: 21).

Petunjuk kegiatan berdasarkan permainan yang dilakukan anak itu dapat memasangkan gambar dengan kata. Maka harus adanya petunjuk kegiatan ketika sebelum memainkannya itu harus melakukan pemanasan terlebih dahulu, sebelum bermain adakan tanya jawab dengan anak tentang nama buah-buahan. Anak mampu menyebutkan banyaknya nama-nama dari jenis buahbuahan (Madyawati, 2012: 21).Jumlah personel sebelum melakukan perminan yanga akan dilakukan anak itu harus adanya jumlah personel Jumlah untuk memainkannya agar kondusif yaitu dengan jumlah 6 orang anak (Madyawati, 2012: 21).

Prosedur terhadap permainan berdasarkan melakukan permainan memasangkan gambar dengan kata yang dilakukan oleh anak.Maka harus adanya prosedur terhadap permainan yaitu salah satunya yaitu bagi anak menjadi tiga kelompok (perkelompok dua orang).Sebelum melakukan kegiatan bermain maka anak terbagi terlebih dahulu sebelum melakukan kegiatan bermain.Meletakkan gambar dan kata secara terpisah berjarak 4 meter dari tempat berdiri anak.Dalam melakukan kegiatan bermain terhadap memasangkan gambar dengan kata.Maka gambar dengan kata itu diletakkan di tempat yang berbeda atau terpisah dengan adanya 
jarak.Dari situlah anak anak bisa memainkannya dengan berlari atau melakukan apapun yang bisa dilakukan anak kemudian ambil gambar dan kata juga (Madyawati, 2012: 21).

Setelah anak melakukan permainannya dan setelah mendapatkan gambar dengan kata.Seorang guru memberikan satu pertanyaan yang berupa lagu yang berkaitan pada permainan yang memsaangkan gambar dengan kata(Madyawati, 2012: 21).Kemudian setelah mengadakan teka-teki tentang buah-buahan, guru memperlihatkan gambar dan kata.Setelah itu anak berlomba mencari tulisannya. Sebelum melakukan permainan seorang guru memberikan ciri-ciri terlebih dahulu, kemudian anak menggambil gambar yang sesuai dengan ciri-ciri yang telah disebutkan oleh guru tersebut, dan Kelompok yang memasangkan gambar dengan kata harus dengan benar ketika ada salah satu yang benar maka dialah yang pemenangnya dalam permainan yang menyenangkan bagi anak (Madyawati, 2012: 22).

Komponen Komunikasi dalam kegiatan berkomunikasian, ada tiga komponen itulah yang berkaitan pada berinteraksi.Ketika suatu pesan yang disampaikan oleh komunikator dengan menggunakan perantara pada media untuk dijadikan sebagai yang disampaikannya kepada komunikan contohnya seorang guru berkomunikasi dengan anak mengenai informasi yang anak itu harus di sampaikan kepada orang tua. Kemudia anak kelas B pada usia 5-6 tahun sudah mampu menyampaikan informasi tersebut melalui surat yang berisi pengumuman, maka komunikator memformulasikan pesan yang akan disampaikan dapat ditafsirkan oleh komunikan dengan baik. Berhasil tidaknya berkomunikasi tergantung dari ketiga komponen pada menggunakan media sebagi penyampaikan pesan kepada orang tersebut.

Perkembangan komunikasi pada anak usia dini (4-6 tahun) ada beberapa dalam komunikasi anak yaitu diantaranya yaitu dapat berpartisipasi dalam percakapan, bahwa anak dapat berpartisipasi pada percakapan dengan temannya maupun dengan guru kelasnya mengenai dalam memecahkan suatu pendapat. Melakukan peran sebagai pendengar yang baik, anak dapat menjadi pendengar yang baik.Ketika seorang guru itu sedang menyampaikan suatu pembelajaran maka anak menjadi pendengar yang baik. bersdasarkan menanggapi pembicaraan orang lain, bahwa anak itu dapat menanggapi pembicaraan orang lain ketika anak tersebut diajak berbicara dalam suatu yang dibicarakan. Percakapan menyangkut berbagai komentar tentang dirinya sendiri, orang lain dan dapat dilihat, bahwa anak dapat berkomentar yang mengenai apa yang pernah dia lihat saat pembelajaran dikelas (yuningsih, $2004: 28$ ). 
Menurut Jamaris dalam buku perkembangan anak usia dini pada penulisnya itu Susanto Ahmad, 2011: 78-79 yaitu bahwa dalam karakter kemampuan komunikasi yang bagian dari perkembangan bahasa anak usia 5-6 tahun adalah sebagai berikut yaitu: Sudah dapat mengucapkan lebih dari 2.500 kosa katam lingkup kosa kata yang dapat di ucapkan anak menyangkut warna,ukuran, bentuk, rasa, bau, keindahan, kecepatan, suhu, perbedaan, perbandingan, jarak, dan permukaan (kasar-halus), anak usia 5-6 tahun sudah dapat melakukan proses sebagai pendengar yang baik. Berpartisipasi dalam suatu percakapan anak mudah dapat mendengarkan orang lain berbicara dan menanggapi pembicaraan sehingga anak dapat bekomunikasi dengan baik.Percakapan yang dilakukan oleh anak 5-6 tahun menyangkut berbagai komentarnya terhadap apa yang dilakukan oleh dirinya sendiri dan orang lain serta apa yang dilihatnya. Anak pada usia 5-6 tahun ini sudah dapat melakukan ekspresi diri, menulis, membaca, dan bahkan berpuisi (susanto, 2011: 78-79).

Tingkat Pencapaian Perkembangan Bahasa Anak usia 5-6 tahun (komunikasi), Peraturan Menteri Pendidikan dan Kebudayaan Nomor 137 Tahun 2014 dalam lingkup perkembangan terhadap bahasa anak yaitu menjawab pertanyaan yang lebih kompleks, menyebutkan kelompok gambar yang memiliki bunyi yang sama, berkomunikasi secara lisan, memiliki perbendaharaan kata, serta mengenal simbol-simbol untuk persiapan membaca, manusia dan berhitung, Menyusun kalimat sederhana dalam struktur lengkap (pokok kalimat-predikat-keterangan), Memiliki lebih banyak kata-kata untuk mengekspresikan ide pada orang lain, Melanjutkan pemahaman konsep-konsep dalam buku cerita.

Indikator Pencapaian Perkembangan Bahasa Anak Usia Dini lahir - 6 tahun Peraturan Menteri Kebudayaan dan Kebudayaan Nomor 146 Tahun 2014 dalam kompetensi dasar dalam indikator yaitua) Mengenal perilaku baik sebagai cerminan akhlak mulia, b)Menunjukkan perilaku santun sebagai cerminan akhlak mulia yaitu dalam indikatornya Berperilaku sopan dan peduli melalui perkataan dan perbuatannya secara spontan (misal: mengucapkan maaf, permisi, terima kasih) mau menolong orang tua, pendidik, dan teman. c) Mengetahui cara memecahkan masalah sehari-hari dan berperilaku kreatif, d) Menyelesaikan masalah sehari-hari secara kreatif, dalam indikatornya yaitu Mampu memecahkan sendiri masalah sederhana yang dihadapi menyelesaikan tugas meskipun menghadapi kesulitan, e) Mengenal lingkungan sosial (keluarga, teman, tempat tinggal, tempat ibadah, budaya transportasi), f) Menyajikan berbagai karya yang berhubungan dengan lingkungan sosial (keluarga, teman, tempat tinggak, tempat ibadah, budaya 
transportasi) dalam bentuk gambar, bercerita, bernyanyi, dan gerak tubuh dalam indikatornya yaitu Menyebutkan nama anggota keluarga dan teman serta ciri-ciri khusus mereka secara lebih rinci (warna kulit, warna rambut, warna jenis rambut, dll). Menjelaskan lingkungan sekitarnya secara sederhana, menyebutkan arah ketempat yang sering dikunjungi dan alat transportasi yang digunakan dan tugas yang dilakukan dalam pekerjaan tersebut membuat dan mengikuti aturan, g) Mengenal lingkungan alam (hewan, tanaman,cuaca, tanah, air, batu-batuan, dll), h) Menyajikan berbagai karya yang berhubungan dengan lingkungan alam (hewan, tanaman, cuaca, tanah, air, batu-batuan, dll) dalam bentuk gambar, bercerita, bernyanyi, dan gerak tubuh, dalam indikatornya yaitu Menceritakan peristiwa-peristiwa alam dengan melakukan percobaan dengan benda-benda yang ada pada lingkungan alam. Menceritakan perkembangan makhluk hidup, i) Memahami bahas reseptif (menyimak dan membaca), j) Menunjukkan kemampuan bahasa reseptif (menyimak dan membaca) dala indikatornya yaitu Menceritakan kembali apa yang didengar dengan kosa kata yang lebih melaksanakan pemerintah yang lebih kompleks sesuai dengan aturan yang disampaikan (misal: aturan untuk melakukan kegiatan memasak ikan), k) Memahami bahasa ekspresif (mengungkapkan bahasa secara verbal dan non verbal), Menunjukkan kemampuan berbahas ekspresif (mengungkapkan bahasa secara verbal dan non verbal), dalam inkatornya yaitu Mengungkapkan keinginan, perasaan, dan mendapat dengan kalimat sederhana dalam berkomunikasi dengan anak atau orang dewasa. Menunjukkan perilaku senang membaca buku terhadap buku-buku yang dikenali.Mengungkapkan perasaan, ide dengan pilihan kata sesuai dengan ketika berkomunikasi.

Seorang guru sebagai adalah komunikator saat disekolah, bahwa guru itu harus berkomunikasi dengan baik agar anak itu dapat ditiru oleh anak (berubah pendapat, sikap, dan perilaku) yang dapat merubah anak itu ada tiga bentuk, yakni untuk mengikuti keinginan seorang guru karena anak iut mengerti bahwa pesan itu penting dan berguna. Untuk membuat anak sebagai komunikan mengikuti keinginan seorang guru sebagai komunikator maka terdapat tiga metode komunikasi dengan anak yang dapat digunakan, yaitu metode informatif, metode persuasif, dan metode koersif antara lain (Dirman, 2014: 35).

MetodeKomunikasi Informatif (informative communication) yakni guru menyampaikan pesan tentang hal-hal baru yang perlu diketahui kepada anak. Seorang anak itu masih membutuhkan kosa kata baru, agar dapat berkomunikasi dengan baik.Maka seorang guru harus mengetahui kemmapuan anak dalam berkomunikasi. Metode Komunikasi Persuasif (persuasive 
communication) yakni seorang guru dapat mempengaruhi sikap, pandangan atau perilaku anak dengan cara membujuk dan mengajak, sehingga agar anak ingin melakukan sesuatu atas dasar keinginan sendiri sehingga memiliki kesadaran sendiri dalam berkomunikasi. Metode KomunikasiInstruktif/Koersif (instructive/coercive communication) Yakni komunikasi seorang guru dengan anak yang dapat mengandung sanksi bagi anak. Apabila tidak melaksanakan sesuatu yang telah ditentukan.Misalnya guru menjelaskan sanksi kepada anak yang hubungan dengan tugas yang diberikan kepada anak kalau tidak dilaksanakan tepat waktu (Dirman, 2014:35-36).Berdasarkan komunikasi anak dengan guru yang dalam proses pembelajaran, maka guru juga dapat menggunakan metode dalam berkomunikasi agar mendapatkan hasil yang lebih baik yaitu metode Secara Langsung, yakni guru memberikan pelajaran atau melaksanakan pembelajaran secara langsung dengan bertahap muka dengan para anak dalam suatu ruangan atau pun di luar ruangan dalam konteks pembelajaran. Hal ini seperti terjadi dikelaskelas.Metode Secara Tak Langsung, yakni guru memberikan suatu pembelajaran melalui suatu media tanpa harus bertatap muka secara langsung dengan anak dan anak pun dapat memperoleh informasi secara luas melalui media tersebut(Dirman, 2014: 36). Metode pembelajaran yang dapat membangun komunikasi dan kerjasama antar anak.Bahwa dengan metode pembelajaran yang membangun komunikasi anak itu sangat penting. Karena dengan melalui metode berkomunikasi anak dapat memudahkan anak untuk berkomunikasi dengan orang lain. Beberapa metode pembelajaran yang membangun komunikasi dan kerja sama antara anak antar yang lain seperti diskusi, latihan bersama teman, tugas dan resitasi kelompok, proyek secara kelompok, eksperimen secara kelompok, bermain peran, dan sosiodrama. Dari masing-masing metode tersebut dapat dijelaskan sebagai berikut: metode diskusi menurut Sudirman, dkk (1991:150), metode diskusi adalah suatu carapelajaran yang dimana anak dihadapkan kesuatu masalah yang dapat berupa penyataan atau pertanyaan yang bersifat problematis untuk dibahas dan dipecahkan bersama (Dirman, 2014: 80).Metode latihan Bersama metode latihan bersama teman memanfaatkan anak yang telah lulus atau berhasil untuk melatih temannya dan ia bertindak sebagai pelatih, pembimbing seorang anak yang lain. Ia dapat menentukan metode pembelajaran yang disukainya untuk melatih temannya tersebut. Setelah teman berhasil atau lulus, kemudian ia bertindak sebagai pelatih bagi seorang teman yang lain (Dirman, 2014:87).Metode Tugas dan Resitasi Kelompok metode pemberian tugas dan realitas kelompok adalah cara pembelajaran dengan memberikan tugas kepada anak secara kelompok untuk melakukan suatu pekerjaan atau 
mengerjakan sesuatu atau hal-hal yang berhubungan dengan materi pembelajaran yang dipelajari dan kemudian membuat laporan hasil tugas tersebut secara kelompok, baik secara lisan maupun tulis (Dirman, 2014: 88). Metode proyek secara kelompok metode proyek atau unit adalah cara pembelajaran yang bertitik tolak dari suatu masalah, kemudian dibahas dari berbagai segi yang berhubungan sehingga untuk memecahkannya secara keseluruhan dan bermakna dari permasalahannya (Dirman, 2014: 89). Metode eksperimen secara kelompokadalah cara pembelajaran dengan memberikan kesempatan kepada anak atau secara kelompok untuk melatik dalam melakukan suatu proses atau percobaan. Dengan metode ini anak diharapkan untuk membuat atau merencanakan suatu eksperimen, untuk melakukan eksperimen, menemukan fakta yang akan terjadi, untuk mendapatkan mengumpulkan data-data, mendapatkan mengendalikan variabel, dan memecahkan suatu masalah yang dihadapi secara nyata (Dirman, 2014: 89).

Metode Bermain Peran ialah suatu cara penugasan pada bahan pembelajaran dengan melalui pengembangan imajinasi anak dan penghayatan anak dengan memerankan sebagai tokoh hidup atau benda mati apa yang diperankannya sebagai tokoh tersebut (Dirman, 2014: 90).

Metode Sosiodrama adalah cara pembelajaran dengan memberikan kesempatan kepada anak untuk melakukan kegiatan dengan memainkan peran yang baik. Dalam memerankan masyarakat untuk bisa bersosial dengan orang lain (kehidupan sosial) (Dirman, 2014: 90).

Bermain dan anak merupakan satu kesatuan yang tidak dapat dipisahkan. Bermain merupakan kebutuhan anak yang harus terpenuhi. Aktivitas bermain yang dilakukan anak, dan aktivitas anak selalu menunjukkan kegiatan bermain yang menyenangkan agar anak itu tidak bosan. Bermain dan anak sangat erat kaitannya oleh karena itu salah satu prinsip pembelajaran pendidikan anak usia dini adalah belajar melalui bermain bahwa pembelajaran anak usia dini itu dengan melalui dengan bermain (Fauziddin, 2014: 6).

Teori-teori modern yang mengkaji tentang bermain tidak hanya menjelaskan mengapa muncul perilaku bermain.Akan tetapi bermain itu muncul pada kesenangan anak saat melakukannya, dari suatu hal yang dilakukannya.Bahwa para tokoh juga berusaha untuk menjelaskan manfaat bermain bagi perkembangan anak dalam komunikasi (Tedjasaputra, 2001: 6). Teori Modern Bermain Bagi Perkembangan Anak Dalam Komunikasi terhadap teori dan peran bermain dalam perkembangan anak yaitu Psikoanalitik yaitu Mengatakan pengalaman traumatik, coping terhadap frustasi, Kognitif- Vygostky yaitu Memajukan berfikir abstrak: belajar dalam kaitan ZPD: pengaturan diri, Kognitif-/Sutton-Smith Singer yaitu Memunculkan 
fleksibilitas dan perilaku dan berfikir; imajinasi dan narasi mengatur kecepatan stimulasi dari dalam dan dari luar, Teori Arousal Modulation yaitu Tetap membuat anak terjaga pada tingkat optimal dengan stimulasi dengan menambah stimulasi, Bateson yaitu Memajukan kemampuan untuk memahami berbagai tingkatan makna.

Anak merupakan salah satu makhluk hidup yang tumbuh dan berkembang lebih pesat pada awal tahun kehidupan. Kualitas perkembangan anak dimasa depannya sangat ditentukan oleh stimulasi yang diperolehnya sejak dini. Perkembangan anak usia dini dengan usia 5-6 tahun itu anak mampu berkomunikasi secara lisan dengan temannya, maupun dengan orang tua dan gurunya. Selain itu anak mampu menyusun kalimat dengan sederhana yang bertujuan anak untuk bisa berkomunikasi dengan lancar. Anak yang memiliki komunikasi yang baik, maka anak itu pasti memilki kosa kata yang banyak agar anak tersebut bisa menuangkan idenya pada orang lain (Desmita. 2012:97-98).

\section{METODE}

Metode peneliti yang digunakan adalah penelitian tindakankelas (classroom action research yaitu peneliti yang dilakukan oleh guru, bekerja sama dengan peneliti (atau dilakukan oleh guru sendiri yang juga bertindak sebagai peneliti) dikelas atau di sekolah tempat ia mengajar dengan adanya penekanan terhadap pembelajaran bagi anak maka pada penyempurnaan atau peningkatan proses pembelajaran kurang memuaskan dan praktis pembelajaran yang disampaikan oleh guru tersebut maka harus adanya pembelajaran yang menyenangkan yang salah satunya itu dengan melakukan permainan memasangkan gambar dengan kata yanga akan dilakukan anak (arikunto, 2006 : 57).

Penelitian tindakan kelas dengan tahapan yaitu perencanaan, pelaksanaan, pengamatan dan refleksi yang diguakan oleh seorang peneliti. Kemudian subjek penelitian yang diambil ialah kelas B yang berjumlah 6 orang perempuan dan 15 orang laki-laki di TK Nurul Wathoni Cirebon. Instrument yang digunakan oleh peneliti yaitu Kemampuan komunikasi dalam karakteristik yaitu berkomunikasi secara lisan, menjawab pertanyaan yang lebih kompleks, meyusun kalimat secara sederhana. Teknik pengumpulan data yaitu menggunakan observasi, wawancara, dan dokumentasi. Analisis data yang digunakan adalah teknik analisis data kualitatif dan kuantitatif. Deskriptif kualitatif merupakan menganalisa data dengan cara menjelaskan dan menggambarkan hasil penelitian dengan kata-kata atau kalimat, sedangkan deskriptif kuantitatif merupakan data yang diperoleh berupa angka-angka untuk mengetahui 
persentase peningkatan kemampuan komunikasi melalui permainan memasangkan gambar dengan kata.Menurut Mulyasa (2009:183), tingkat keberhasilan yang diharapkan terjadi minimal $75 \%$ dengan kriteria tiap sekor.

a. Ketuntasan individu dan klasikal

$$
\mathrm{S}=\frac{\mathrm{R}}{\mathrm{N}} \times 100 \%
$$

Keterangan:

$\mathrm{S}=$ Persentase Ketuntasan Individual

$\mathrm{R}=$ Skor Yang diperoleh

$\mathrm{N}=$ Skor Maksimal

b. Ketuntasan Belajar Klasikal dengan rumus

$$
\begin{aligned}
& \mathrm{PK}=\frac{\mathrm{JT}}{\mathrm{JS}} \mathrm{X} 100 \% \\
& \text { Keterangan: } \\
& \mathrm{PK}=\text { Persentase Ketuntasan Klasikal } \\
& \mathrm{JT}=\text { Jumlah Anak yang Tuntas } \\
& \mathrm{JS}=\text { Jumlah Seluruh Anak }
\end{aligned}
$$

Anak dikatakan tuntas secara klasikal apabila anak tersebut mencapai nilai $75 \%$. Jika anak dikatakan belum tuntas, maka anak tersebut belum mencapai nilai $75 \%$.

\section{HASIL DAN PEMBAHASAN}

Kemampuan komunikasi melalui permainan memasangkan gambar dengan kata pada kelompok B di TK Nurul Wathoni Cirebon. Permainan ini dapat meningkatkan terhadap perkembangan bahasa anak dalam kemampuan komunikasi. Bahwa anak itu sudah cukup bagus dalam kemampuan komunikasi saat melakukan permainan dalam memasangkan gambar dengan kata. Bahwa seorang peneliti mempratikkan memasangkan gambar dengan kata, respon anak anak kelas Bsangat senang, dan setelah anak menempelkan gambar dengan kata kemudian anak menceritakan kembali yang telah ditempelkannya. Anak mampu berkomunikasi karena mengenalkan gambar dengan kata, anak mengetahui huruf sesuai dengan gambarnya yang mereka lihat. Oleh karena itu melakukan sesuatu yang akan dilakukannya baik itu makan, minum, berbicara pasti adanya komunikasi dengan orang lain.Kemudian komunikasi anak juga sangat penting bagi anak karena komunikasi bertujuan untuk berkomunikasi yang digunakan dalam kehidupan sehari-hari.

Peningkatan kemampuan komunikasi melalui permainan memasangkan gambar dengan kata pada kelompok B di TK Nurul Wathoni Cirebon dalam instrument dalam penilaian pada 
anak yang diambil dari permendikbud nomor 137 tahun2014 yaitu anak yang memiliki keberanian tampil di depan kelas dalam berkomunikasi secara lisan. Anak mampu menjawab pertanyaan dari guru, anak mampu memaparkan kata sesuai dengan gambar, anak mampu menyebutkan gambar dan huruf, setalah memaparkan gambar dengan kata kemudian anak mampu menceritakan kembali gambar yang di tempelkannya. Kemudian anak mampu menyebutkan teman sekelasnya untuk bergiliran maju untuk memasangkan gambar dengan kata.

Manfaat adanya permainan memasangkan gambar dengan kata pada kelompok B di TK Nurul Wathoni Cirebon. Permainan memasangkan gambar dengan kata ini adalah melatih anak untuk selalu berkomunikasi dengan orang lain, agar anak dapat berani di depan kelas itumuncul rasa percaya diri dalam diri anak. Anak melakukan permainan dengan mencari kata yang ditentukan, kemudian di tempelkannya, dari situ anak mengenalkan huruf dan gambar maka termasuk pada perkembangan bahasa.Tujuan ini adalah memahami anak dalam meningkatkan perkembagan bahasa anak. Terdapat peningkatan yang diperoleh anak melalui permainan memasangkan gambar dengan kata yang dimulai dari prasiklus dari diagram dibawah ini:

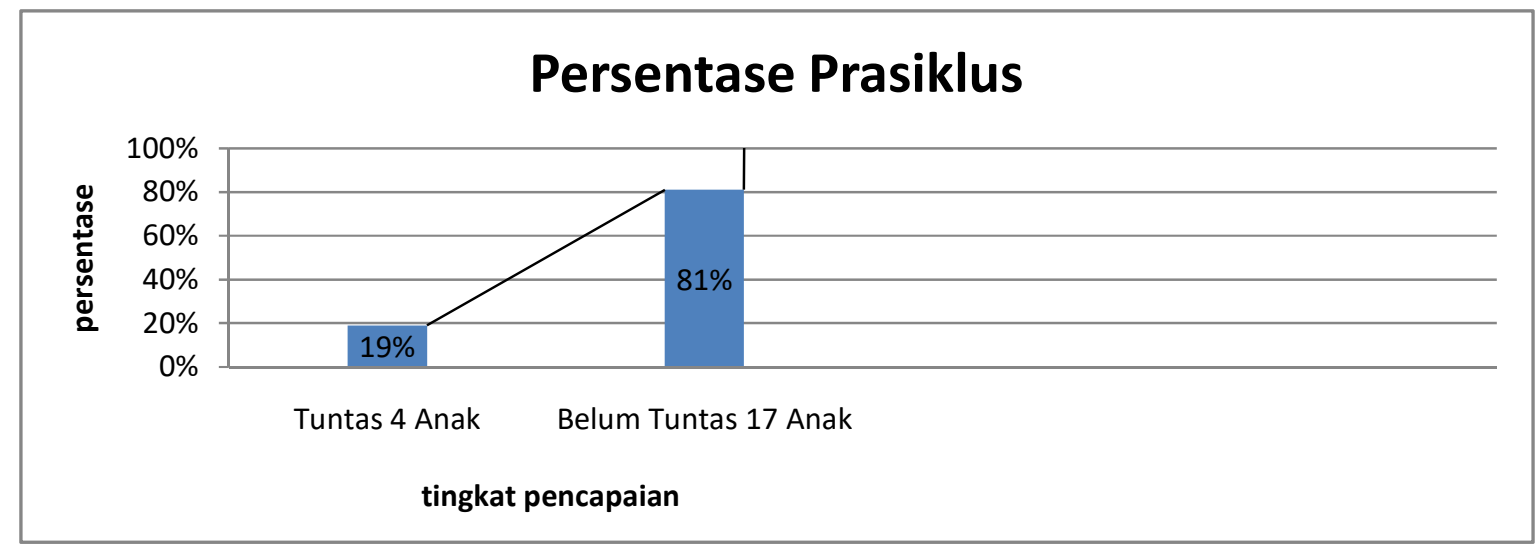

Diagram 1 Persentase Pra Siklus

Berdasarkan hasil yang telah komunikasi anak melalui permainanmemasangkan gambar dengan kata, pada pra siklus 19,04\% yaitu bagi anak yang tuntas berjumlah 4 orang dan anak yang tidak tuntas berjumlah 17 anak maka rata-ratanya itu $81 \%$. 


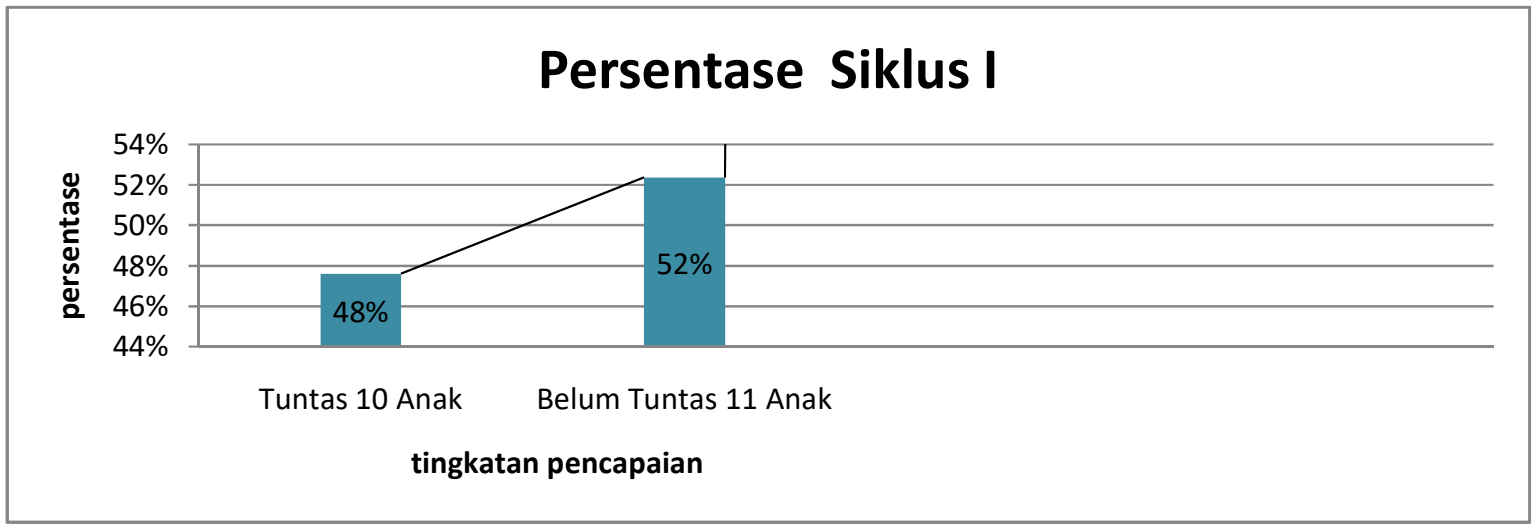

Diagram 2 Persentase Siklus I

Padasiklus I tingkat perkembangannya hanya mencapai $47,61 \%$ bagi anak yang tuntas yang berjumlah 10 anak dan anak yang belum tuntas yang berjumlah 11 anak maka rata-ratanya yaitu $52 \%$.

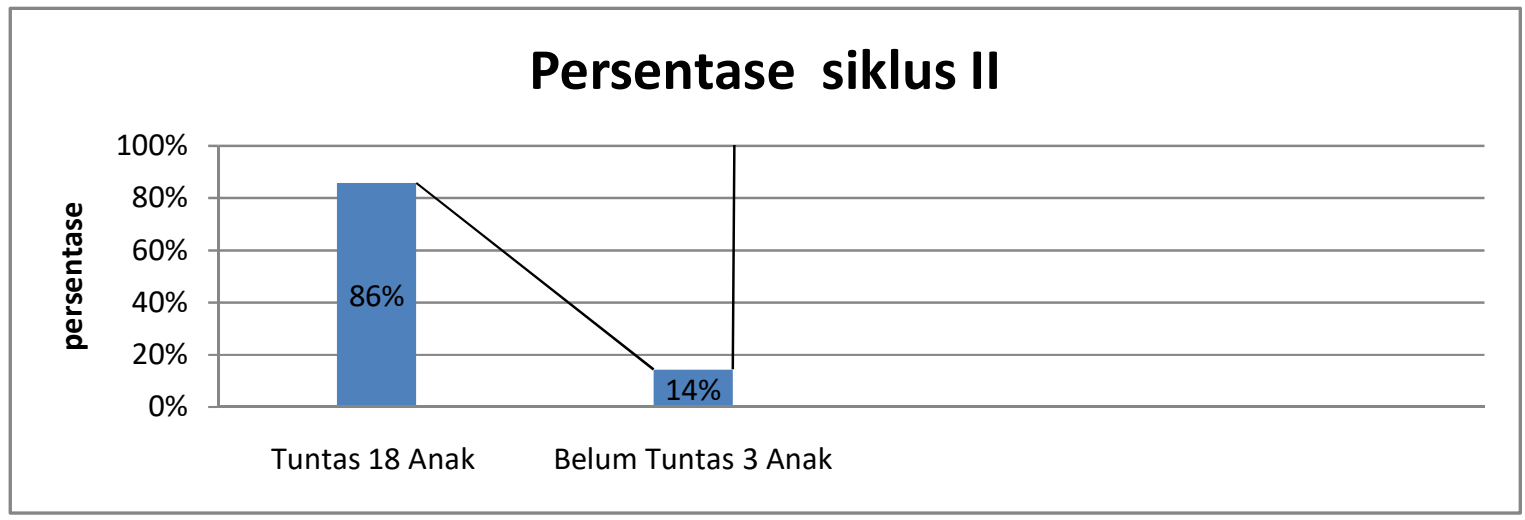

Diagram 3Diagram Persentase Siklus II

Padasiklus II untuk menghitung ketuntasan secara individual dan secara klasikal, dan tingkat pencapaian anak yang tuntas adalah 18 anak yang tuntas atau sekitar 85,71 \% , sedangkan anak yang belum tuntas ada 3 anak atau sekitar 14,28 \%. 


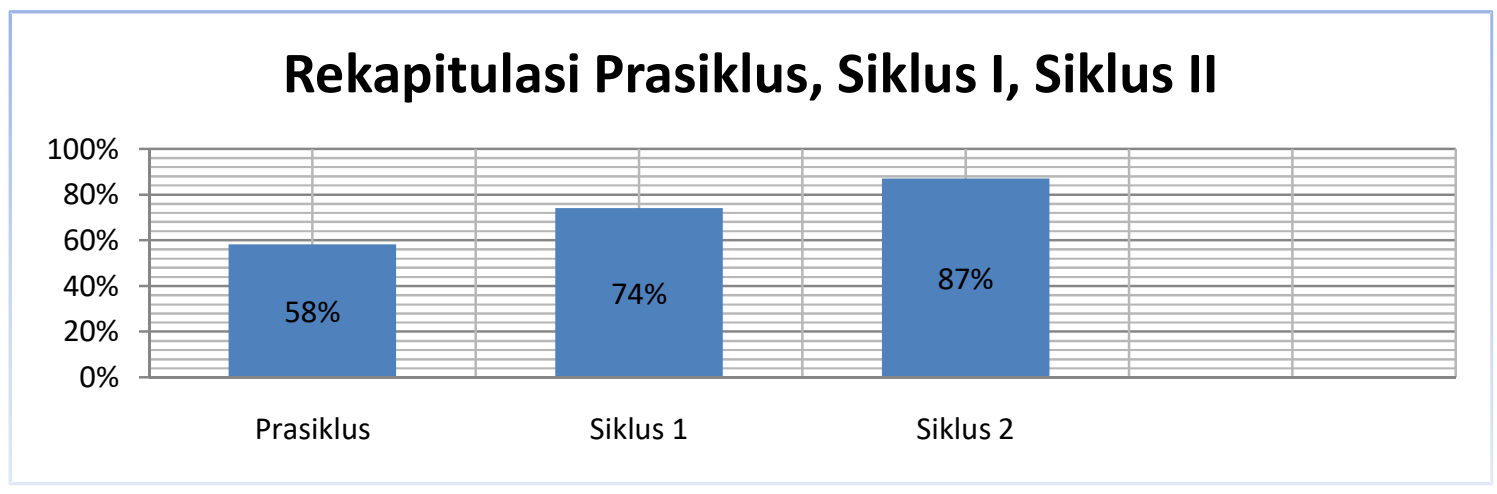

Diagram 4 Rekapitulasi Pra Siklus, Siklus1 Dan Siklus 2

Berdasarkan data diatas dapat dilihat bahwa dalam prasiklus mencapai 58,28\%. Berdasarkan penelitian pada siklus I dapat mencapai peningkatan mencapai 74,04\% kemudian pada siklus II juga mencapai peningkatan mencapai 87,19\% .Tabel persentase pada prasiklus, siklus 1 dan siklus 2 pada tabel dibawah ini:

Tabel 4.17

Persentase Prasiklus, Silus 1, Siklus 2

\begin{tabular}{|c|l|l|l|l|}
\hline No & \multicolumn{1}{|c|}{ Nama } & Prasiklus & Siklus 1 & \multicolumn{1}{|c|}{ Siklus 2 } \\
\hline 1 & Aditya & $53 \%$ & $93 \%$ & $96 \%$ \\
\hline 2 & Aep & $75 \%$ & $65 \%$ & $96 \%$ \\
\hline 3 & Alif & $50 \%$ & $93 \%$ & $100 \%$ \\
\hline 4 & Ais & $50 \%$ & $93 \%$ & $78 \%$ \\
\hline 5 & Aulia & $75 \%$ & $59 \%$ & $100 \%$ \\
\hline 6 & Aufa & $50 \%$ & $93 \%$ & $96 \%$ \\
\hline 7 & Azra & $75 \%$ & $62 \%$ & $100 \%$ \\
\hline 8 & Ahwan & $53 \%$ & $75 \%$ & $71 \%$ \\
\hline 9 & Brian & $46 \%$ & $53 \%$ & $81 \%$ \\
\hline 10 & David & $65 \%$ & $93 \%$ & $100 \%$ \\
\hline
\end{tabular}




\begin{tabular}{|c|c|c|c|c|c|}
\hline 11 & Dimas & $71 \%$ & $62 \%$ & $93 \%$ & \\
\hline 12 & Farrah & $50 \%$ & $93 \%$ & $93 \%$ & \\
\hline 13 & Fatur & $53 \%$ & $53 \%$ & $93 \%$ & \\
\hline 14 & Ferry & $56 \%$ & $93 \%$ & $71 \%$ & \\
\hline 15 & Ibra & $53 \%$ & $53 \%$ & $96 \%$ & \\
\hline 16 & Ibnu & $50 \%$ & $68 \%$ & $100 \%$ & \\
\hline 17 & Jesi & $53 \%$ & $93 \%$ & $93 \%$ & \\
\hline 18 & Loly & $75 \%$ & $59 \%$ & $96 \%$ & \\
\hline 19 & Khansa & $71 \%$ & $59 \%$ & $100 \%$ & \\
\hline 20 & Raihan & $50 \%$ & $75 \%$ & $71 \%$ & \\
\hline 21 & Ziad & $50 \%$ & $68 \%$ & $100 \%$ & \\
\hline \multirow{2}{*}{\multicolumn{2}{|c|}{ Total }} & $\begin{array}{cc}\text { Tuntas } & 4 \\
(19,04 \%) & \end{array}$ & $\begin{array}{cc}\text { Tuntas } & 10 \\
(47,61 \%) & \end{array}$ & $\begin{array}{c}\text { Tuntas } \\
(85,71 \%)\end{array}$ & 18 \\
\hline & & $\begin{array}{l}\text { Belum Tuntas } \\
17(80,95 \%)\end{array}$ & $\begin{array}{l}\text { Belum } \\
\text { Tuntas } \\
(52,3 \%)\end{array}$ & $\begin{array}{l}\text { Belum } \\
\text { Tuntas } \\
(\mathbf{1 4 , 2 \% )}\end{array}$ & 3 \\
\hline
\end{tabular}

Dapat disimpulkan pada prasiklus anak yang tuntas berjumlah 4 anak dan anak yang belum tuntas berjumlah 17 anak. Pada siklus 1 anak yang tuntas berjumlah 10 anak dan anak yang belum tuntas berjumlah 11 anak. Berdasarkan siklus 2 dapat mencapai peningkatan pada anak yang tuntas yaitu berjumlah 18 anak dana anak yang belum tuntas yang berjumlah 3 anak.

\section{SIMPULAN}

Kemampuan komunikasi pada anak di kelas B di TK Nurul Wathoni Cirebon bahwa anak itu sudah cukup bagus dalam kemampuan komunikasi saat melakukan permainan dalam memasangkan gambar dengan kata. Melakukan sesuatu hal yang akan dilakukannya baik itu makan, minum, berbicara pasti adanya komunikasi dengan orang lain.Kemudian komunikasi anak juga sangat penting bagi anak karena komunikasi bertujuan untuk berkomunikasi yang digunakan dalam kehidupan sehari-hari.

Penerapan permainan memasangkan gambar dengan kata di TK Nurul Wathoni Cirebon. Dalam penerapan permainannya itu, seorang peneliti memberikan tawaran/timbal balik kepada anak-anak semangat untuk tampil didepan kelas dengan memasangkan gambar dan kata yang sudah disediakan didepan.Kemudian anak-anak semangat dalam mengikuti kegiatan 
permainan tersebut untuk maju kedepan.Setelah itu anak-anak memasangkan gambar, kemudian salah satu anak menyusun kata yang sesuai dengan gambar yang dipasangkannya.Dan sebaliknya anak yang memasangkan gambar lalu peneliti yang menunjuk anak untuk maju, untuk menguji dalam pemahaman anak dalam memasangkan gambar dengan kata.Setelah berhasil dalam memasangkan gambar dengan kata, lalu salah satu anak yang berani tampil untuk bercerita tentang gambar yang dipasangkannya.Oleh karena itu, seorang peneliti membuat permainannya dengan menggunakan media kain flanel, baik itu gambar maupun kata-katanya.Kemdian permainan tersebut dihiasi media kain flanelnya agar anak itu menarik perhatian anak.Dapat disimpulkan sehingga peneliti menggunakan judul "Peningkatan Kemampuan Komunikasi Melalui Permainan Memasangkan Gambar Dengan kata Pada Anak Kelompok B Di TK Nurul Wathoni Cirebon".Judul ini bertujuan untuk meningkatkan kemampuan komunikasi anak atau terhadap perkembangan bahasa pada anak dengan melalui permainan juga sebagai media permainan yang menarik bagi anak.

Peningkatan kemampuan komunikasi melalui permainan memasangkan gambar dengan kata pada kelompok B di TK Nurul Wathoni Cirebon. Pada penelitian terhadap kegiatan prasiklus dengan pencapaian dalam persentasenya yaitu 58,28\%. Pada penelitian terhadap kegiatan siklus 1 dengan mencapai persentasenya yaitu 74,04\%.Peneliti melakukan penggulangan dalam melakukan kegiatannya, sehingga peneliti melakukan siklus II yang persentasenya itu $87,19 \%$. Jadi dapat disimpulakan yaitu siklus I mencapai 74,04\% dan siklus II mencapai $87,19 \%$ dalam perselihannya yaitu $13,15 \%$.

\section{DAFTAR PUSTAKA}

Arikunto Suharsimi. 2006. Penelitian Tindakan Kelas. Jakarta: Bumi Aksara.

Desmita. 2012. Psikologi Perkembangan Peserta Didik. Bandung: PT Rosdakarya.

Dirman. 2014. Komunikasi Dengan Peserta Didik. Jakarta: PT Rineka Cipta.

Djamarah, Bahri Syaiful. 2014. Pola Asuh Orang Tua Dan Komunikasi Dalam Keluarga Upaya Membangun Citra Membentuk Pribadi Anak. Jakarta: Renika Cipta.

Kementerian Pendidikan dan Kebudayaan Nomor 137 Tahun 2014 tentang Kurikulum Pendidikan Anak Usia Dini. 
Kementerian Pendidikan dan Kebudayaan Nomor 146 Tahun 2014 tentang Kurikulum Pendidikan Anak Usia Dini.

Khorida, Muhammad Fadillah Lilif Mualifatu. 2013. Pendidikan Karakter Anak Usia Dini. Yogyakarta: AR-RUZZ MEDIA.

Mulyana, Deddy. 2005. Ilmu Komunikasi Suatu Pengantar. Bandung: Rosdakarya.

Mulyasa. 2012. Praktek Penelitian Tindakan Kelas. Bandung: Remaja Rosda Karya.

Prawiradilaga Salma, Dewi. 2007. Prinsip Disain Pembelajaran. Jakarta: Kencana Prenada Media Group.

Susanto, Ahmad. 2011. Perkembanagan Anak Usia Dini Pengantar Berbagai Aspeknya. Jakarta: Kencana Prenada Media Group

Suyadi, Maulidya Ulfah. (2013). Konsep Dasar PAUD, Bandung : PT Remaja Rosdakarya

Tedjasaputra S, Mayke. 2001. Bermain, Mainan, Dan Permainan Untuk Pendidikan Usia Dini. Jakarta: PT Grasindo

Yuningsih, Nining. 2004. Pengimbasan Hasil Diklat Instruktur Tingkat Dasar Guru KanakKanak Inovatif Tanggal 9-12 Agustus 2004. Majalengka 